tion, and Dr. Robert Sutherland, medical adviser and secretary to the Council. The school is intended primarily for those who have to do with the training and care of children and young people-teachers, youth leaders, health visitors, school nurses, educa. tional and medical administrators, training organisers, welfare superintendents, sanitary inspectors and students. The object of the school is to present the general content, methods and practice of health education. Mornings will be devoted to lectures in physiology, psychology, the biology of infection, sociology and health, as well as to lectures, demonstrations and discussions on the various methods and applications of health education. Evening lectures will deal with wider educational, psychological, social, philosophical, and spiritual aspects. There will be opportunity for discussion under experienced leaders, for viewing health films and acquiring technique in visual aids. The afternoons will be left free for optional visits, sports and physical recreation under expert leadership. Local authorities will be asked to consider the possibility of nominating students to attend the school. The inclusive fee will be $£ 1414 s$. Further details can be obtained from the Medical Adviser and Secretary, the Central Council for Health Education, Tavistock House, Tavistock Square, London, W.C.1.

\section{Root-infecting Fungi}

A BRIEF review by S. D. Garrett of recent work upon several root-infecting fungi (Endeavour, 4, 15; July 1945) contains outlines of two new techniques for the prevention of fungal attacks in tropical countries. R. P. N. Napper's method for rubber plantations (which are started with a minimum of jungle clearance in this case) involves half-yearly inspection of the roots of the young trees by trained squads. The mycelium of any root-disease fungus which is found is traced back to its source, usually a jungle root, which is eradicated. Similarly, $\mathbf{R}$. Leach found, in Nyasaland, that the root diseases of plantations arose from fungi developing in moribund roots of jungle stumps. If the jungle trees are ringbarked one year before felling, the roots are entered by saprophytic and not parasitic fungi. Mr. Garrett refers to the beneficial effect of the steam-sterilization of greenhouse soils even when root-infecting fungi are not a danger. $\mathrm{He}$ directs attention, also, to the important part such fungi have played in making unprofitable the monoculture of soil-exhausting crops such as wheat in Australia and cotton in the United States.

\section{Old Scientific Books}

DURING the last few years Herbert Reichner, of 34 East 62nd Street, New York, 21, has issued a number of catalogues offering for sale early and classic works on all branches of science and philosophy. Nos. 3-6 bear the following titles: Civilization through Five Centuries; French Science and Thought; Great Thinkers from Albertus Magnus to Albert Einstein; Literature, History, Art and Science. These catalogues are well printed, extensively annotated, and indexed; and each of the last three includes a useful list of reference works that have been consulted. Many important and uncommon works are listed, and the catalogues are full of interest for students of the history and early literature of science. They should afford collectors and librarians, if their purses are sufficiently well lined, a number of opportunities to fill gaps in their collections.

\section{Royal Astronomical Society: Officers for 1946}

THE following have been elected officers of the Royal Astronomical Society : President: Prof. H. H. Plaskett, Savilian professor of astronomy, University of Oxford. Vice-Presidents : the Rev. M. Davidson; Dr. H. R. Hulme, scientific adviser to the Air Ministry ; Prof. E. A. Milne, Rouse Ball professor of mathematics, University of Oxford; Mr. J. H. Reynolds. Treasurer : Sir Harold Spencer Jones, Astronomer Royal. Secretaries: Prof. W. H. McCrea, professor of mathematics in the University of London (Royal Holloway College) ; Mr. D. H. Sadler, superintendent of the Nautical Almanac. Foreign Secretary: Prof. F. J. M. Stratton, professor of astrophysics, University of Cambridge. Council : Miss M. G. Adam, chief assistant (astronomy), University Observatory, Oxford ; Mr. B. C. Browne, lecturer in geodesy, University of Cambridge; Dr. H. A. Brück, John Couch Adams astronomer, University of Cambridge ; Mr. D. L. Edwards, director of the Norman Lockyer Observatory, Sidmouth; Dr. M. A. Ellison; Mr. F. J. Hargreaves; Dr. A. Hunter, assistant, Royal Observatory, Greenwich; Dr. E. M. Lindsay, director of the Armagh Observatory; Dr. E. H. Linfoot, lecturer in mathematies, University of Bristol ; Mr. P. J. Melotte, assistant, Royal Observatory, Greenwich; Mr. F. J. Sellers; Dr. W. H. Steavenson.

\section{Announcements}

RECENT appointments at the University of Sheffield include the following: Dr. Charles Horrex to be lecturer in chemistry; Dr. Eric Hutchinson and Mr. Basil G. Skinner to be assistant lecturers in chemistry; Mr. J. H. Woodhead to be lecturer in metallurgy. The title of emeritus professor has been conferred upon Prof. W. E. S. Turner, who retired from the chair of glass technology on December 31.

Dr. T. F. West, recently chief chemist to Stafford Allen \& Sons, Ltd., is joining the board of the Hygienic Chemical Co., Ltd., as director in charge of scientific research and development.

THE following appointments have recently been made by the Colonial Office: J. B. Clegg, to be agricultural officer, Tanganyika; S. Hunter, to be agricultural officer, Nigeria ; 'T. S. Jones, to be agricultural officer, Sierra Leone; A. Lesslie, to be agricultural superintendent, Gold Coast; R. H. Montgomery, to be agricultural officer, Nigeria; R. T. Gray, to be assistant conservator of forests, Nigeria ; K. Sargent, to be assistant conservator of forests, Kenya; D. I. Shirlaw, to be assistant conservator of forests, Nigeria ; P. T. Preston, to be veterinary officer, Kenya; L. G. Cooper, to be assistant conservator of forests, Nigeria; A. C. Frith, to be assistant conservator of forests, Sierra Leone; J. D. Brown, principal agricultural officer, Nigeria, to be deputy director of agriculture, Nigeria; A. V. Gibberd, agricultural officer, Nigeria, to be senior agricultural officer, Nigeria; A. F. Posnette, botanist, West African Cocoa Research Institute, to be senior specialist, West African Cocoa Research Institute; S. D. Ross, agricultural officer, Nigeria, to be senior agricultural officer, Nigeria; F. S. Collier, deputy chief conservator of forests, Nigeria, to be chief conservator of forests, Nigeria; D. A. Bates, geologist, Gold Coast, to be senior geologist, Gold Coast. 